International Journal of Child, Youth and Family Studies (2015) 6(4.1): 646-661

\title{
THE RELEVANCE OF NON-COLORBLIND TALK BETWEEN WHITE WOMEN AND NON-WHITE CHILDREN IN THE UNITED STATES: A DISCUSSION
}

\author{
Tracy L. Robinson-Wood
}

\begin{abstract}
The social construction of race in Western, and particularly American, contexts has contributed to white people not having to think about the personal meaning of being white and not needing to understand the relevance of race in the lives of people of color. The implications of this racial dynamic are considered in light of American demographic data documenting that the majority of mothers of black and white biracial children are white women. A number of American national and international research studies and literature reviews from Britain, Canada, and New Zealand that investigate white women's experiences mothering non-white children are reviewed. The majority of the research on interracial families emphasizes black and white families as they represent the largest racial groups. This demographic trend will frame the current discussion. Historical dimensions of race in America are discussed, including the social construction of race, which has implications for the content of racial socialization messages transmitted by white mothers to their non-white children. An overview of cultural forces that contribute to colorblind talk between white mothers and their non-white children is provided.
\end{abstract}

Keywords: Interracial families; white mothers; biraciality; racial socialization; racism; whiteness

Tracy L. Robinson-Wood, Ed.D. is a Professor in the Department of Applied Psychology, Bouvé College of Health Sciences at Northeastern University, 360 Huntington Ave., Boston, Massachusetts 02115. E-mail: tr.robinson@neu.edu 
International Journal of Child, Youth and Family Studies (2015) 6(4.1): 646-661

Never in the history of the United States have there been so many white women mothering non-white children, through adoption and by birth. Black and white biracial children are products of both marital and non-marital unions. Since the repeal of miscegenation laws in 1967, black and white marriages have been on the increase in a post-1960s Civil Rights Movement era. Nearly two-thirds of black and white marriages are between black men and white women (U.S. Census Bureau, 2011). Between 1990 and 2010, this dyad saw a 132\% increase in biracial births. The black woman-white man dyad, a much smaller group, saw a $152 \%$ increase in biracial births in the same period (B. Hamilton, personal communication, January 11, 2013). As shown in Tables 1 and 2, the majority of black and white biracial people have white mothers.

Table 1

Child Births to White Women and Black Men

\begin{tabular}{|l|c|c|}
\hline 1990 & 2010 & $1990-2010$ \\
\hline 37,661 & 87,469 & $132 \%$ increase \\
\hline
\end{tabular}

Note. Data obtained from the Division of Vital Statistics via personal communication from B. Hamilton, January 11, 2013.

Table 2

Child Births to Black Women and White Men

\begin{tabular}{|c|c|c|}
\hline 1990 & 2010 & $1990-2010$ \\
\hline 11,818 & 29,835 & $152 \%$ increase \\
\hline
\end{tabular}

Note. Data obtained from the Division of Vital Statistics via personal communication from B. Hamilton, January 11, 2013.

Over nine million people, nearly 3\% of the U.S. population, report more than one race (Humes, Jones, \& Ramirez, 2011). The largest multiple-race category and the one that increased most between 2000 and 2010, is white and black, with 1.8 million people. Between 2000 and 2010, the two or more races population increased 32\% total, whereas the U.S. population grew 10\% (Jones \& Bullock, 2012). Of the nearly 4 million children born in the U.S. each year, 77\% were to white women (Martin et al., 2012), and most of these were monoracial. In interracial relationships between white and non-white, gendered and racial patterns are seen. Biracial black and white children are most likely to have a white mother and a black father. The majority of Eurasian children have an Asian mother and a white father. Among Native people, who have high rates of biraciality and multiraciality, in particular with white people, there are similar numbers of white women and Native women mothering biracial and multiracial Native children (Robinson, 2001). Latinos (people from Latin America and other parts of the Latin Diaspora), can be of any race and skin color, and are currently 17\% of the U.S. population, or 51 million people (Ennis, Rios-Vargas, \& Albert, 2011). During the 2010 census, more than half (54\%) of Latinos identified as white. For varying reasons, some Latinos racially identify as white on the 
census form, even though this might not match the way they routinely self-identify in daily life. Such complicating factors can make racial meanings difficult to interpret. The United States census contributes to this difficulty by categorizing people from Northern Africa as white, despite the variety of skin-color hues, from white to dark brown, among people from Egypt and other parts of the African continent (Hixson, Hepler, \& Kim, 2011).

Historically, the experience of women mothering children who are phenotypically different from themselves is not new. Black women have a long history of raising children with a different skin-color hue. White male slave-owners subjugated black slave women, with whom they had mulatto (black and white) children. Black women also functioned as surrogate mothers in their forced roles as caretakers of white people and their children. By reason and motivation, black women have been compelled to examine the implications of race and skin color in their interactions with both white and black children (Hurtado, 1989). In America, both prior to and since its inception in 1776, normalcy, privilege, and power have been ascribed to white maleness. In contrast, black women, due to systemic forces of racism, sexism, and classism, continue to be disproportionately represented among those at the bottom of the income and occupational hierarchy. Even among highly educated black women, discourses situate black graduate students and faculty as less intellectually competent than white people (Robinson-Wood et al., in press). Race, gender, and class discrimination are interlocking sources of oppression, privileging some while disadvantaging others (Landry, 2007); this explicates the chronic economic, educational, physical, and mental health disparities that prevail today among black women. Race has grandmaster status and as such, has the power to eclipse achieved identities while imposing a melanin tax on visible black women (Robinson-Wood, in-press; Thomas, 2004). Black parents prepare their children to move through a world that is racially unjust and treats black people according to socially-constructed devaluations of non-white skin; the black women and men those children become have acquired survival skills, such as interrogating race and understanding its importance in daily negotiations (Rodriguez, McKay, \& Bannon, 2008).

\section{Historical and Contemporary Dimensions of the Social Construction of Race}

The identity challenges that exist for biracial and multiracial people are rooted in historical conceptions of color; in particular, for black people, any European bloodline was negated due to "the one-drop rule” (Gillem, Lincoln, \& English, 2007). The one-drop rule emerged in the Southern United States during slavery and vilified any visible trace of African ancestry. The onedrop rule was traditionally and, in the era of Jim Crow segregation, legally, understood as disallowing a white identity, regardless of physical appearance, to anyone who had at least 1/32 black ancestry. White people had the most social power and privilege, followed by mixed-race people, who were often light-skinned blacks, while darker-skinned blacks had the least social power and privilege. Despite educational and work privileges extended to them, mulattos were considered black due to hypodescent, which refers to the process wherein mixed-raced individuals are assigned to the group with less social status (e.g., the black mother during slavery). These inequities emanated from patriarchy and created division in the black community that exists to this day (Robinson-Wood, 2013). Ironically, between 2000 and 2010, the south, in spite of its history of a defiant stance against the federal order requiring previously segregated public schools to admit black school children, legalized bans against black and white interracial marriage, and the racial terror and violence of the Ku Klux Klan, saw a 49\% increase in the population of two or more races (Jones \& Bullock, 2012). 
Racial inequities are experienced in multiple ways. One clear example is demonstrated by Goldsmith, Hamilton, and Darity (2006, 2007), who, after controlling for productivity-linked characteristics, discovered greater gaps in wages between darker-skinned blacks and whites than between lighter-skinned blacks and whites, that is, black people with lighter complexions earned more money than darker-skinned blacks. Colorism is an intraracial system of inequality in which the allocation of privileges and disadvantages is based on skin color (Hunter, 2002, 2005; Wilder \& Cain, 2011; Ward, Robinson-Wood, \& Boadi, in press). Colorism is a problem that exists today (Ward, Robinson-Wood, \& Boadi, in press). It refers to internalized bias and favor for a distinct set of phenotypical characteristics that include lighter skin, Eurocentric facial features (e.g., aquiline nose, thin lips), and "good" hair texture (e.g., hair that is long and straight or wavy, rather than tightly coiled or kinky). This type of social categorization supports an ideology in which being light is valued over being dark; colorism shapes perceptions of who is attractive, intelligent, and desirable (Burton, Bonilla-Silva, Ray, Buckelew, \& Hordge, 2010; Hall, 2010).

Despite declines in the blatancy of Jim Crow racism, racism is pervasive and continues to exist in covert and sophisticated ways (Bobo, 2011; Sue, 2010). Race correlates with neighborhood type, renter or home ownership status, the home's worth, the marital status of the adults in the home, infant mortality, longevity, poverty, and incarceration rates (Hamilton, Goldsmith, \& Darity, 2009). In 2010, black men were more than six times as likely as white men to be incarcerated (Drake, 2013). Compared to the general population and to whites, in particular, black people have lower levels of wealth and higher never-married rates. The poverty rate for black people is nearly three times that of non-Hispanic whites, at 27\% compared to 9.6\% (U.S. Census Bureau, 2013). Poverty rates are $27.2 \%$ for Native people, $23.5 \%$ for Latinos, and $10.5 \%$ for Asians.

Poverty has far-reaching consequences. Social and economic prospects are worse for children who grow up poor. People who are poor experience more chronic health problems, live in crowded conditions, contend with noise, are more likely to be injured on the job, and are more vulnerable to obesity and violence. There is also greater social isolation in high-poverty neighborhoods. People have limited neighborhood services. Moreover, given that class influences the geography and demography of neighborhoods, homogenous social networks perpetuate the recycling of the same information (Dominguez \& Arford, 2010; Dominguez \& Watkins, 2003).

When white people voluntarily segregate themselves from blacks, the process is referred to as white habitus. Here, white solidarity is promoted, as is people's positive view of themselves. A consequence is a distorted view of black people and limitations on the development of meaningful cross-cultural relationships between white and black people (Bonilla-Silva, Goar, \& Embrick, 2006).

After controlling for education, tremendous economic discrepancies exist between black and white people, with past and contemporary racism accounting for much of the disparity (Darity et al., 2006). While both black and white Americans believe in equality, white Americans, more than black Americans, support the belief that blacks are as well off as whites in terms of jobs, incomes, health care, and schooling (Smedley, Stith, \& Nelson, 2003). Compared to white people, black and white biracial people tend to be younger, have lower median incomes for men and women, higher poverty rates among children and the elderly, higher never-married 
International Journal of Child, Youth and Family Studies (2015) 6(4.1): 646-661

rates, and less likelihood of home ownership (Jones, 2005). Thus, the racial and social profiles descriptive of black Americans extend to black and white biracial people.

In all aspects of society, racism is embedded and has shaped the lives and actions of white men and women (Frankenberg, 1993), including the lives and actions of white women who mother black and white biracial children. Becoming personally aware of white privilege, and of the subtle and overt ways in which white women in interracial families are affected by racism and whiteness, is work that relies on social networks and sustained connection to others, in particular people of color (Britton, 2013; Spanierman, Todd, \& Anderson, 2009). When biracial children do not have sustained interaction with healthy communities of color, where the child is provided opportunities to learn accurate information about and practice his or her culture, how are race and ethnicity, as identity components, nurtured and developed? Is the white parent aware of the relevance of black culture in the child's life?

\section{Racial Socialization}

Research has been conducted with a variety of ethnically and racially diverse U.S.- born families, including Asian, Latino, and Native American, as well as with immigrant families. The transmission of families' beliefs, values, and practices to their children are reflected in the native language being spoken, the preparation of native foods, and observation of native traditions (Hughes et al., 2006). Historically, the majority of racial socialization research has focused on black American families (Frabutt, Walker, \& MacKinnon-Lewis, 2002; Rodriguez et al., 2008). To prepare children to live with cultural pride as well as to live in a world where racial inequity predominates, black parents have long engaged in racial socialization practices. In doing so, they have talked to (i.e., lectured) their children about how to survive and thrive in a society where race matters. Such messages are delivered in conversations about the type of clothing to avoid so as not to be seen as unkempt and lazy, stereotypes that have assailed black and other people of color, how to interpret blatant racism so it does not destroy a child's sense of self-worth, and offering explanations as to why it is important to stay in school so that one can "make something of oneself.” Thomas (1999), a black woman, gave an example of racial socialization. Her parents told her "she would have to work twice as hard as her white peers to be successful and not to be frustrated by that challenge” (pp. 35-36). Black parents deliver humanistic messages along with racial content due to the daunting task among black parents of helping children contend with racial inequality. Researchers have found that racial socialization strategies that focus primarily on racial barriers are associated with negative outcomes whereas cultural pride, an aspect of racial socialization, may have a positive effect on children's behavior (Rodriguez et al, 2008).

Rollins and Hunter (2013) employed a quantitative methodology in their analysis of maternal race and racial socialization messages. There were 73 biological mothers of biracial children in their sample, which was taken from a 1991 public-use subsample (Wave I) of the longitudinal Maryland Adolescent Development in Context Study. Forty-two percent of mothers identified themselves as black, $40 \%$ as white, $11 \%$ were Asian, $4 \%$ were Latin, $1.4 \%$ were American Indian, and 1.4\% identified as other. Nearly 1,500 families with a 12- or 13-year-old child attending public school were in the original sample. Rollins and Hunter (2013) identified three approaches to racial socialization from their thematic analysis of mothers' racial socialization messages. These approaches were labeled promotive, protective, and passive. With promotive racial socialization, mothers emphasize equality and encourage a color-blind 
worldview. There is no preparation for or direct teaching about racial discrimination. A protective racial socialization approach prepares children for racial discrimination. Children are given a sense of self as a member of a racial group and are taught to stand up for their rights but to be respectful. Mothers characterized by a passive racial socialization approach either do nothing to prepare their children for discrimination or did not answer the question posed by the interviewer. Racial socialization approaches did not vary by maternal race; however, mothers of black and white biracial children engaged least frequently in silent racial socialization messages. Rollins and Hunter (2013) concluded that black parents of biracial children may be more aware of the role that skin-color hue plays in society whereas parents of non-black biracial children (e.g., Eurasian or Latino) may not have encountered negative racial experiences with their child. Parents of African descent seemed to have awareness of their children's racialized experiences, an awareness that may not have been present among parents of racially ambiguous children.

These racial differences in awareness may largely be due to the fact that within sociallyconstructed discourses of race in America, whiteness is normative and safe whereas blackness is threatening and non-standard (Robinson-Wood, 2013). White people tend not to be: (a) watched while shopping; (b) perceived to be a threat or dangerous when walking down a street; (c) concerned, when relocating to a new neighborhood, that neighbors will think of them as bringing the neighborhood down; or (d) worried that people will regard them as lazy, incompetent, or unqualified. These are unearned privileges associated with an immutable characteristic of white skin (McIntosh, 1988). Granted, the year of McIntosh's work is dated but the content of her message is, unfortunately, relevant and timely in the 21st century.

\section{The Relevance of Non-Colorblind Talk}

Social constructionist theory maintains that society plays a role in the production and perpetuation of understandings about the world (Gergen, 1985). Racialized discourses are also socially produced (Robinson-Wood, 2013). Weedon (1987) defined discourses "as ways of constituting knowledge, together with the social practices, forms of subjectivity and power relations which inhere in such knowledges and relations between them. Discourses are more than ways of thinking and producing meaning. They constitute the 'nature' of the body, unconscious and conscious mind and emotional life of the subjects they seek to govern” (p. 105). Because discourses tend to be subtle, yet pervasive, they hold enormous power. People may be unaware of their location within and proximity to discourses. Location means "identifying where one resides in this society on a continuum from privilege to oppression in relation to various contextual aspects of the self, such as ethnicity, gender, sexual orientation, religion, and class status” (Vasquez \& Magraw, 2005, pp. 66-67). For example, Verbian (2006), in her examination of racialized discourses in feminist and multicultural literature teaching and learning, acknowledged the importance of Canadian research that explores the lived experiences of white women who, like she, are mothers to black and white biracial children. Referencing the research literature, she acknowledged that white birth mothers of black and white biracial children are subjected to familial discourses about their sexuality and maternal competence and are publicly scrutinized in ways that white women within monoracial heterosexual unions are not. 
International Journal of Child, Youth and Family Studies (2015) 6(4.1): 646-661

Several dynamics tend to favor the use of non-colorblind talk by white women:

- First, interrogating blackness and whiteness against the backdrop of a racially stratified society, as opposed to colorblindness, may help white mothers assist their children with negotiating race (Robinson-Wood, 2011; Twine, 2010a). According to Neville, Spanierman, and Doan (2006), colorblindness is defined as the "denial, distortion, and/or minimization of race and racism” (p. 276), and is a dominant racially-based framework used to justify and explain away racial inequalities in the United States. The view that "race should not and does not matter" (Neville, Lilly, Duran, Lee, \& Browne, 2000, p. 60), appears admirable and seems to embrace multiculturalism. However, ignoring race distorts the reality of racism and upholds the status quo.

- Second, colorblindness appears to protect white people from recognizing and addressing racial inequalities in society, alleviate cognitive dissonance, and encourage inaction, while preserving the privileges that many white people receive from the current system (Neville et al., 2000). Thus, colorblindness differs vastly from racial literacy, and may keep white mothers from developing the skills that could help their black and white biracial children navigate a world where race and skin color matter.

- Third, white people have limited understanding about the effects and consequences of race, whiteness, and racism on their lives (Bonilla-Silva et al., 2006; Britton, 2013; Pinderhughes, 1989), as well as on the lives of people of color. As a function of growing up in a culture where race tends not to designate whiteness, white women have not been required to interrogate, unpack, and personalize the meaning of whiteness for themselves.

- Fourth, race tends to be a fragile and fractured topic between black and white people, particularly in the United States, due primarily to the history of legal enslavement of black people by white people, which established a system of white superiority and black inferiority that still manifests today. The fugitive nature of race discourages open talk about race and instead encourages "not seeing" race.

- Fifth, racial status (racial categorization and designation, typically based on phenotype, over which people do not have control) and racial identity development (one's cultivated racial awareness and consciousness of colorblindness) are distinct concepts.

- Finally, ethnically and racially similar groups function as a protective buffer, and include racially diverse, allied kin, and social networks in interracial families where race is a construct in which people are aware of its power to impact one's lived experiences (Darity et al, 2006; Dominguez \& Watkins, 2003; Twine, 2010a).

Mothers have considerable influence on children's expressions of racial identity (Miville, Constantine, Baysden, \& So-Lloyd, 2005). As such, informed, open, and clear (non-colorblind) dialogue about race and racism between white mothers and their non-white children could foster a child's grasp of race as a social and personal construct that impacts people's lives. 
International Journal of Child, Youth and Family Studies (2015) 6(4.1): 646-661

\section{Review of the Research on White Mothers of Biracial Children}

A range of phenotypical expressions exists among biracial children from visibly white, ambiguous, to black. Black and white biracial children may present as phenotypically different (e.g., lighter in skin color, hair color, and eye color) from their monoracial black peers (Gillem et al., 2007). Through interviews, biracial and multiracial adults have described encounters with racism that happened while they were growing up. Being asked, "What are you?" was common (Miville et al., 2005). Among biracial youth in particular, a need exists for dialogue about race (Herman, 2004; Schwartz, 1998). It is not that biracial and multiracial people in the general population are more dissatisfied, unhappy, or uncomfortable with their racial identity. Being mixed-race creates unique challenges (Shih \& Sanchez, 2005). Udry, Li, and Hendrickson-Smith (2003), in their analysis of Add Health data, taken from a large representative national sample in the United States, compared mixed-race adolescents to single-race adolescents. The authors concluded that teens identifying with more than one race were at a higher health and behavior risk when compared with teens identifying with one race. The stress of identity conflict may explain this risk. The racial identity development of biracial youth is more complicated than for monoracial peers. Some biracial children are psychologically conflicted about choosing one racial identity over another based on their phenotype, their neighborhood, or, in the case of divorce, the race of their custodial parent (Poston, 1990).

O’Donoghue (2004) observed that the majority of the 11 white women she interviewed from the east and northeast of the United States, including New England, could identify their ethnic lineage but "did not consider it a major factor in their socialization" (p. 74). Women had not considered to any great extent how their lineages contributed to their enculturation. White mothers who do not attach importance to their ethnic identity or racial awareness, may not regard race and ethnicity as salient to rearing their mixed-race children.

To assess racial identification, Brunsma and Rockquemore (2001) conducted research with 177 white and black biracial people from two colleges located in a large mid-western city. The majority of respondents (56\%), irrespective of skin-color hues, defined themselves as "ambiguous though most people assume I am black." A majority also considered themselves to have border identities - they understood themselves as neither black nor white but as exclusively biracial, an identity that was not validated by others. Most border biracial participants experienced the world as black people not as white people. Although more multiracial identities may be available to black and white biracial people (Brunsma, 2006; Roth, 2005), and may be a function of racial socialization experiences, socially constructed racial meanings appear to be an enduring feature of the United States (Omni \& Winant, 2006).

In a later study, Rockquemore (2002) conducted semi-structured qualitative interviews with 16 black and white biracial individuals who were taken from a larger research sample of participants from the American northeast, the south, and the mid-west. She found that more of her biracial interviewees were raised by white women than by black women. The biracial adults who had been raised by white mothers frequently reported being aware of their white parents' explicit racism and experienced their mothers' racist views of their black father. Rockquemore's biracial participants also reported experiencing negative interactions with monoracial black people. Biracial women were more likely than biracial men to report negative interactions. Socially constructed and often negative valuations about skin color, body size, and eye color 
typified the content of these encounters. Some biracial women in this study gave evidence that they had internalized negative messages about black people who were generally described as unemployed, ill-mannered, and substance abusers. The implications of this research are that the existence of intimate relationships between black men and white women is not evidence of an evolved racial identity on the part of the latter, nor of distance from dominant racialized discourses (e.g., blacks are lazy and less intellectually capable compared to whites).

Research on white women mothering non-white children has been conducted in Britain, Canada, and New Zealand. These countries are similar to America concerning the presence of racially and ethnically different people, including a large presence of African people from the African Diaspora in Canada and Britain. Colonialism, involving First Nation indigenous people, is contained in each country's narrative, which means power, privilege, and patriarchy are consistent themes, irrespective of the political, historical, and ideological differences across these Western bodies. Tribal people have undergone ethnic cleansing and trauma; their cultural ways of living, languages, land ownership, and humanity have come under attack. In America, the legacy of colonialism is palpable and prominent, reflecting cultural violence, the highest of poverty rates, genocide, and educational and health-related disparities among First Nation indigenous people.

Twine (2010a) conducted an extensive ethnography of more than 40 white British mothers in relationships with men of African descent. She also interviewed black partners, friends, and extended family members. Her work introduced the concept of racial literacy which refers to "discursive, material, and cultural practices in which parents train themselves and their children to recognize, name, challenge, and manage various forms of everyday racism” (p. 8). Twine found that white women in interracial families who had racial literacy skills were different from those who did not, with respect to: (a) racial composition of friendship networks as children and adults; (b) informal education from friendship networks and experience in antiracist political groups; (c) exposure to overt racism and immersion in multicultural communities as children; (d) relationships with black women; and (e) the racial consciousness of the children's black father (p.259). In a different study (Twine, 2010b) taken from a subset of another study, Twine identified discourses regarding white women who co-exist in relationships with black men as: (a) sexually adventurous; (b) an economic and social asset due largely to the symbolic nature of her white skin; and (c) a cultural threat to the black family.

Speaking from a British context, Britton (2013) discussed the importance of uncovering whiteness in interracial families, given the construction of whiteness as normative and imbued with privilege, while being invisible. By uncovering whiteness, the impact of race and racism for all members of interracial families can be examined and better understood.

Robinson-Wood (2010) conducted 28 semi-structured qualitative interviews with white mothers of biracial children in the United States and in New Zealand, and found that in both countries, there were study participants who initiated conversations about race with their children, although such initiation of race discussions was the exception and not the norm. Whereas some of the white mothers in the study minimized discussions about race, others avoided the topic. The talks that these white mothers primarily engaged in with their non-white children did not emphasize race but focused on citizenship, success, respectability, coming from a good family, getting a good education, being a good person, and possessing self-worth. The children of these mothers were encouraged to believe that they were just as good as anyone else. 
International Journal of Child, Youth and Family Studies (2015) 6(4.1): 646-661

Although not the entire sample, there were American and New Zealand mothers who took part in this study that reported being silent about race and attributed their silence about race to multiple forces: (a) a desire to protect children from the painful reality of racism; (b) not knowing how to talk about race; (c) waiting for the appropriate time to discuss race; (d) children's young age (all children in the study were at least five years of age); (e) children's silence about race, which for some mothers, translated into the insignificance of race as a topic; and, (f) not perceiving race to be a topic that required discussion. A parent's silence about race and racism will not protect a child from experiencing racism (Robinson-Wood, 2010). When children's responses to, or meaning-making from, racial name calling, discourses, or the fact that brown and black people are more likely than white people to serve food in the cafeteria, clean bathrooms, or be incarcerated, are not talked about, children are left vulnerable. They are vulnerable to discovering, perhaps painfully on their own, the structural inequality of race in America.

\section{Summary}

America and the world are experiencing a biracial baby boom. Although biracial and mixed-race identities have existed in the black community for centuries, for the first time in the history of the United States, white women are mothering the majority of biracial black and white children. In addition, there are increasing numbers of black women mothering children from unions with white men. The largest "two or more races" group noted in the 2010 census consists of white and black biracial people. Despite the growing reality of interraciality across gender and race dyads, race and racism continue to structure economic and social opportunities, including quality of medical care, educational access, residential type, longevity, and income. Race and racism also impact psychological functioning and explicate the lingering nature of racial inequality between black and white people in America. Being mixed-race creates unique challenges (Herman, 2004; Shih \& Sanchez, 2005). As well, the racial identity development of biracial people is more complicated than for monoracial youth. Children benefit from parents who have racial literacy, shaped through interactions with people of color, and are able to interrogate race against the backdrop of a racially stratified society, particularly as it pertains to their children's negotiations with contestations of racial identities and position within a race status hierarchy (Twine, 2010a).

Due largely, however, to the social construction of whiteness in America, white people often lack understanding about both the effects and consequences of race and racism on their own lives and on the lives of people of color (Pinderhughes, 1989). Not surprisingly, lack of insight into race and racist attitudes have been documented among white women, including those in intimate relationships with black men and who mother children conceived from these unions (Rockquemore, 2002).Intimate relationships with black men do not denote white women's proximity to or attitudes about racism. Moreover, previous research has revealed that race-related dialogue initiated by white mothers of biracial youth is the exception, not the norm (RobinsonWood, 2010, 2011). Talks have centered primarily on success, respectability, social capital (e.g., coming from a good family), getting a good education, being a good person, and possessing selfworth. These messages are transmitted in black families but for most black parents, racial injustice has been central to racial socialization messages. 
International Journal of Child, Youth and Family Studies (2015) 6(4.1): 646-661

\section{Conclusion}

The relevance of white women talking directly and openly about race with their black and white biracial children was discussed in light of the social construction of race in Western, and in particular, American contexts, that support white people not having to think about the personal meaning of being white. Clearly, the conversation about race has always been important. It is especially important now that, for the first time in the history of America, the majority of black and white biracial people have white mothers. For most white people, including women who are mothering biracial black and white children, not having to interrogate race, not uncovering whiteness, or choosing to racially segregate one's residential location and interpersonal relationships from black people are consequences of white privilege. That said, black and white biracial children, particularly children who appear visibly black, are vulnerable to experiencing forms of racism similar to their monoracial black peers. Children look to their mothers, who, as white women, have had a different set of racial realities in comparison to their children. Learning that one's children are targets of discrimination because of the color of their skin can trigger feelings of powerlessness, sadness, and rage among white mothers. Such feelings, however, do not translate into the tools to skillfully converse about racism.

Research is needed on the impact of whiteness and racism on all family members within interracial families. Unpacking whiteness to include white Latinas and Native women, who are phenotypically white, would allow researchers to investigate the intersections of white skin with ethnicity. Not to disentangle race from ethnicity contributes to phenotypically white women being treated as monolithic and ethnically Caucasian. In addition, research to ascertain similarities and differences in racial socialization messages transmitted by black women in interracial black and white families, compared to white women in interracial black and white families, would be beneficial. In order to engage in informed, open, and honest talk about race with black and white biracial children, racial literacy is critical for white women. Racial literacy is cultivated through interpersonal relationships and psychosocial work with racially different people where racial meanings are explored, experienced, and contested. For most white people, working collaboratively with people of color to discover white privilege and reshape racial identity is work that has not been required given the social construction of whiteness, which seems to coincide with and is in support of colorblind talk and the minimization of race. Biracial black and white lives matter. Non-colorblind talk between white mothers and their black and white biracial children attests to this realization. 
International Journal of Child, Youth and Family Studies (2015) 6(4.1): 646-661

\section{References}

Bobo, L. D. (2011). Somewhere between Jim Crow \& post-racialism: Reflections on the racial divide in America today. Daedalus: Journal of the American Academy of Arts \& Sciences, 140, 11-36. http://dx.doi.org/10.1162/daed_a_00091

Bonilla-Silva, E., Goar, C., \& Embrick, D. G. (2006). When Whites flock together: White habitus and the social psychology of Whites' social and residential segregation from blacks. Critical Sociology, 32, 229-254. Retrieved from http://dx.doi.org/10.1163/156916306777835268 http://archives.library.illinois.edu/erec/University Archives/2401001/Production_website/pages/StewardingExcellence/When Whites Flock Together The Social Psychology of White Habitus.pdf

Britton, J. (2013). Researching white mothers of mixed parentage children: The significance of investigating whiteness. Ethnic and Racial Studies, 36, 1311-1322. http://dx.doi.org/10.1080/ 01419870.2013 .752101

Brunsma, D. L. (2006). Mixed messages: Doing race in the color-blind era. In D. Brunsma (Ed.), Mixed messages: Multiracial identities in the "color-blind” era (pp.1-11). Boulder, CO: Lynne Reinner.

Brunsma, D. L., \& Rockquemore, K. A. (2001). The new color complex: Appearances and biracial identity. Identity, 1, 225-246. http://dx.doi.org/10.1207/s1532706xid0103_03

Burton, L. M., Bonilla-Silva, E., Ray, V., Buckelew, R., \& Hordge Freeman, E. (2010). Critical race theories, colorism, and the decade's research on families of color. Journal of Marriage and Family, 72, 440-459. http://dx.doi.org/10.1111/j.1741-3737.2010.00712.x

Darity, W., Mason, P. L., \& Stewart, J. B. (2006). The economics of identity: The origin and persistence of racial identity norms. Journal of Economic Behavior and Organization, 60, 283-305. http://dx.doi.org/10.1016/j.jebo.2004.09.005

Dominguez, S., \& Arford, T. (2010). It's all about who you know: Social capital and health in low-income communities. Health Sociology Review, 19 (1), 114-129. http://dx.doi.org/10.51 72/hesr.2010.19.1.114

Dominguez, S., \& Watkins, C. (2003). Creating networks for survival and mobility among African American and Latin American low-income mothers. Social Problems, 50 (1), 111135. http://dx.doi.org/10.1525/sp.2003.50.1.111

Drake, B. (2013). Incarceration gap widens between whites and blacks. Washington, D.C: Pew Research Trust.

Ennis, S. R., Rios-Vargas, M., \& Albert, N. G. (2011). The Hispanic population. 2010 Census Briefs. Washington, DC: U.S. Census Bureau. Retrieved from http://www.census.gov/prod/cen2010/briefs/c2010br-04.pdf

Frabutt, J., Walker, A., \& MacKinnon-Lewis, C. (2002). Racial socialization messages in African American families: Descriptive analysis and family process correlates. Journal of Early Adolescence, 22, 200-217. 
International Journal of Child, Youth and Family Studies (2015) 6(4.1): 646-661

Frankenberg, R. (1993). Growing up white: Feminism, racism, and the social geography of childhood. Feminist Review, Thinking Through Ethnicities, 45, 51-84. http://dx.doi.org/1 $0.1057 /$ fr. 1993.38

Gergen, K. J. (1985). The social constructionist movement in modern psychology. American Psychologist, 40, 266-275. http://dx.doi.org/10.1037/0003-066x.40.3.266

Gillem, A. R., Lincoln, S. K., \& English, K. (2007). Biracial populations. In M. G. Constantine (Ed.), Clinical practice with people of color: A guide to becoming culturally competent (pp. 104-1241). New York, NY: Teachers College Press.

Goldsmith, A., Hamilton, D., \& Darity, W. A. (2006). Shades of discrimination: Skin tone and wages. Skin Tone Discrimination and Economic Outcomes, 96, 242-245.

Goldsmith, A., Hamilton, D., \& Darity, W. A. (2007). From dark to light: Skin color and wages among African Americans. Journal of Human Resources, 42, 701-738. http://dx.doi.org/10. 3368/jhr.xlii.4.701

Hall, R. (2010). An historical analysis of skin color discrimination in America: Victimism among victim group populations. New York, NY: Springer Science. http://dx.doi.org/10.1007/978-1-4419-5505-0

Hamilton, D., Goldsmith, A., \& Darity, W.A. (2009). Shedding 'light' on marriage: The influence of skin shade on marriage for Black females. Journal of Economic Behavior \& Organization, 72 (1), 30-50. http://dx.doi.org/10.1016/j.jebo.2009.05.024

Herman, M. (2004). Forced to choose: Some determinants of racial identification in multiracial adolescents. Child Development, 75, 740-748. http://dx.doi.org/10.1111/j.1467-8624.2004.00703.x

Hixson, L., Hepler, B. B., \& Kim, M. O. (2011). The White population: 2010. 2010 Census Briefs. Washington, DC: U.S. Census Bureau. Retrieved from https://www.census.gov/prod/cen2010/briefs/c2010br-05.pdf

Hughes, D., Rodriguez, J., Smith, E. P., Johnson, D. J., Stevenson, H. C., \& Spicer, P. (2006). Parents' ethnic-racial socialization practices: A review of research and directions for future study. Developmental Psychology, 42, 747-770. http://dx.doi.org/10.1037/0012-1649.42.5.747

Humes, K., Jones, N., \& Ramirez, R. (2011). Overview of Race and Hispanic Origin:2010. 2010 Census Briefs. Washington, DC: U.S. Census Bureau. Retrieved from http://www.census.gov/prod/cen2010/briefs/c2010br-02.pdf

Hunter, M. (2002). “If you're light, you're alright”: Light skin color as social capital for women of color. Gender and Society, 16, 175-193. http://dx.doi.org/10.1177/08912430222104895

Hunter, M. (2005). Race, gender and the politics of skin tone. Abingdon, UK: Routledge. http://dx.doi.org/10.4 324/9780203620342

Hurtado, A. (1989). Relating to privilege: Seduction and rejection in the subordination of white women and women of color. Signs, 14, 843-855. http://dx.doi.org/10.1086/494546

Jones, N. A. (2005). We the people of more than one race in the United States. Census 2000 special reports. Washington, DC: U.S. Census Bureau.

Jones, N. A., \& Bullock, J. (2012). The two or more races population: 2010. 2010 Census briefs. Washington, DC: U.S. Census Bureau. 
International Journal of Child, Youth and Family Studies (2015) 6(4.1): 646-661

Landry, B. (2007). Race, gender, and class: Theory and methods of analysis. Upper Saddle River, NJ: Merrill Pearson Education.

Martin, J. A., Hamilton, B. E., Ventura, S. J., Osterman, J. K., Wilson, E. C., \& Mathews, T. J. (2012). Births: Final data for 2010. National Vital Statistics Report, 61, 1-17.

McIntosh, P. (1988). White privilege and male privilege: A personal account of coming to see correspondence through work in Women's Studies. (Working Paper No. 189). Wellesley, MA: Wellesley College Center for Research on Women.

Miville, M. L., Constantine, M. G., Baysden, M. F., \& So-Lloyd, G. (2005). Chameleon changes: An exploration of racial identity themes of multiracial people. Journal of Counseling Psychology, 52, 507-516. http://dx.doi.org/10.1037/0022-0167.52.4.507

Neville, H. A., Lilly, R. L., Duran, G., Lee, R. M., \& Browne, L. (2000). Construction and initial validation of the Color-Blind Racial Attitudes Scale (CoBRAS). Journal of Counseling Psychology, 47, 59-70. http://dx.doi.org/10.1037/0022-0167.47.1.59

Neville, H. A., Spanierman, L., \& Doan, B. (2006). Exploring the association between colorblind racial ideology and multicultural counseling competencies. Cultural Diversity and Ethnic Minority Psychology, 12, 275-290. http://dx.doi.org/10.1037/1099-9809.12.2.275

O’Donoghue, M. (2004). Racial identity development in White mothers of bi-racial, black-white Children. Affilia, 19 (1), 68-84. http://dx.doi.org/10.1177/0886109903260795

Omni, M., \& Winant, H. (2006). Racial formations. In T. Ore (Ed.), The social construction of difference and inequality: Race, class, gender, and sexuality (pp. 19-29). Boston, MA: McGraw-Hill.

Pinderhughes, E. (1989). Understanding race, ethnicity, and power: The key to efficacy in clinical practice. New York, NY: Free Press.

Poston, W. S. C. (1990). The biracial identity development model: A needed addition. Journal of Counseling and Development, 69, 152-155. http://dx.doi.org/10.1002/j.1556-6676.1990.tb01477.x

Robinson, T. L. (2001). White mothers of non-white children. Journal of Humanistic Counseling and Development, 40, 171-184. http://dx.doi.org/10.1002/j.2164-490x.2001.tb00115.x

Robinson-Wood, T. L. (2010). “Is that your mom?” A qualitative investigation of White mothers of non-White children in the United States and New Zealand. Journal of Ethnographic and Qualitative Research, 22, 226-238.

Robinson-Wood, T. L. (2011). “It makes me worry about her future pain”: A qualitative investigation of White mothers of non-White children in the United States. Women \& Therapy, 34, 331-344. http://dx.doi.org/10.1080/02703149.2011.591678

Robinson-Wood, T. L. (2013). The convergence of race, ethnicity, and gender: Multiple identities in counseling (4th ed.). Upper Saddle River, NJ: Pearson. 
International Journal of Child, Youth and Family Studies (2015) 6(4.1): 646-661

Robinson-Wood, T. L., Balogun, O., Boadi, N., Matsumoto, A., Popat, A., Fernandes, C., \& Zhang, X. (in press). Worse than blatant racism: A phenomenological investigation of microaggressions among highly educated black women. Journal of Ethnographic and Qualitative Research.

Rockquemore, K. A. (2002). Negotiating the color line: The gendered process of racial identity construction among Black/White biracials. Gender \& Society, 16, 485-503. http://dx.doi.org/10.1177/0891243202016004005

Rodriguez, J., McKay, M. M., \& Bannon, W. M. (2008). The role of racial socialization in relation to parenting practices and youth behavior: An exploratory analysis. Social Work in Mental Health, 6, 30-54. http://dx.doi.org/10.1080/15332980802032409

Rollins, A., \& Hunter, A. G. (2013). Racial socialization of biracial youth: Maternal messages and approaches to address discrimination. Family Relations, 62(1), 142-153. http://dx.doi.org/10.1111/j.1741-3729.2012.00748.x

Roth, W. D. (2005). The end of the one-drop rule? Labeling of multiracial children in black intermarriages. Sociological Forum, 20, 35-67. http://dx.doi.org/10.1007/s11206-005-1897-0

Schwartz, W. (1998). The identity development of multiracial youth. ERIC/CUE Digest, 37. Retrieved from ERIC database (ED425248).

Shih, M., \& Sanchez, D. T. (2005). Perspectives and research on the positive and negative implications of having multiple racial identities. Psychological Bulletin, 131, 569-591. http://dx.doi.org/10.1037/0033-2909.131.4.569

Smedley, B. D., Stith, A. Y., \& Nelson, A. R. (Eds.). (2003). Unequal treatment: Confronting racial and ethnic disparities in healthcare. Washington, DC: National Academies Press. http://dx.doi.org /10.17226/12875

Spanierman, L. B., 'lodd, N. K., \& Anderson, C. J. (2009). Psychosocial costs of racism to Whites: Understanding patterns among university students. Journal of Counseling Psychology, 56, 239-252. http://dx.doi.org/10.1037/a0015432

Sue, D. W. (2010). Microaggressions in everyday life: Race, gender, and sexual orientation. Hoboken, NJ: John Wiley \& Sons.

Thomas, A. J. (1999). Racism, racial identity, and socialization. Journal of Counseling \& Development, 77, 35-37. http://dx.doi.org/10.1002/j.1556-6676.1999.tb02413.x

Thomas, V. G. (2004). The psychology of Black women: Studying women's lives in context. Journal of Black Psychology, 30, 286-306. http://dx.doi.org/10.1177/0095798404266044

Twine, F. W. (2010a). A White side of Black Britain: Interracial intimacy and racial literacy. Durham, NC: Duke University Press. http://dx.doi.org/10.1215/9780822393559

Twine, F. W. (2010b). White like who? The value of whiteness in British interracial families. Ethnicities, 10, 292-312. http://dx.doi.org/10.1177/1468796810372306

Udry, J. R., Li, R. M., \& Hendrickson-Smith, K. (2003). Health and behavior risks for adolescents with mixed race identity. American Journal of Public Health, 93, 1865-1870. http://dx.doi.org/10.2105/ajph.93.11.1865

U.S. Census Bureau (2011). Families and living arrangements. Table 60. Married couples by race and Hispanic Origin of Spouses: 1980 to 2009. 
International Journal of Child, Youth and Family Studies (2015) 6(4.1): 646-661

U.S. Census Bureau. (2013). Current Population Survey, Annual Social and Economic Supplements. Families and living arrangements. Table 16. Distribution of the Poor, by Age and Race: 1959 to 2013.

Vasquez, H., \& Magraw, S. (2005). Building relationships across privilege: Becoming an ally in the therapeutic relationship. In M. Mirkin, K. Suyemoto, \& B. Okun (Eds.), Psychotherapy with women: Exploring diverse contexts and identities (pp. 64-83). New York, NY: Guilford Press.

Verbian, C. (2006). White birth mothers of black/white biracial children: Addressing racialized discourses in feminist and multicultural literature teaching and learning color consciousness in black families. Journal of the Association for Research on Mothering, 8, 213-220.

Ward, J. V. (2000). The skin we're in: Teaching our children to be emotionally strong, socially smart, and spiritually connected. New York, NY: Free Press.

Ward, J. V., Robinson-Wood, T. L., \& Boadi, N. (in press). Resisting everyday colorism: Strategies for identifying and interpreting the problem that won't go away. In Carla Monroe (Ed.), Routledge Research in Educational Equality and Diversity. Race and colorism in education. New York, NY: Routledge.

Weedon, C. (1987). Feminist practice and poststructuralist theory. New York, NY: Blackwell Publishing.

Wilder, J., \& Cain, C. (2011). Teaching and learning color consciousness in Black families: Exploring family processes and women's experiences with colorism. Journal of Family Issues, 32, 577-604. http://dx.doi.org/10.1177/0192513x10390858 